\title{
Selective Internal Radiation Therapy (SIRT) as Conversion Therapy for Unresectable Primary Liver Malignancies
}

\author{
Alessandro Cucchetti ${ }^{a}$ Alberta Cappellib Giorgio Ercolani ${ }^{\mathrm{a}}$ \\ Cristina Mosconi $^{b} \quad$ Matteo Cescon ${ }^{a}$ Rita Golfierib \\ Antonio Daniele Pinna ${ }^{a}$ \\ ${ }^{a}$ Department of Medical and Surgical Sciences-DIMEC, S.Orsola-Malpighi Hospital, Alma Mater Stu- \\ diorum-University of Bologna, ${ }^{b}$ Radiology Unit, Department of Diagnostic and Preventive Medicine, \\ S.Orsola-Malpighi Hospital, Bologna, Italy
}

\section{Key Words}

Cholangiocellular carcinoma · Hepatocellular carcinoma - Radioembolization · Surgery · Yttrium-90

\begin{abstract}
Background: Many patients with primary liver cancers are not candidates for surgery, and systemic therapies are seldom effective. Selective internal radiation therapy (SIRT) has been shown to obtain partial and even complete response in unresectable primary tumors. As a "side effect", SIRT can induce contra-lateral liver hypertrophy. Tumor response to SIRT can be sufficient to allow disengagement from normal vital structures whose involvement is the cause of the initial unresectability. The contra-lateral hypertrophy can thereby increase the future liver remnant (FLR) volume to over the safe threshold so that extended hepatectomy can be performed. Summary: A review of the available literature was performed to assess the tumor response and liver hypertrophy that can be expected after SIRT, in order to de-
\end{abstract}

A. Cuccheti and A. Cappelli contributed equally to the present work (shared first authorship).

Alessandro Cucchetti, MD
Department of Medical and Surgical Sciences-DIMEC, S.Orsola-Malpighi Hospital, Alma Mater Studiorum-University of Bologna Via Massarenti 9, 40138 Bologna (Italy)

Tel. +39 051 6363721, E-Mail aleqko@libero.it 
lineate whether SIRTcan play a role in conversion therapy for resectability of primary liver malignancies. Key Message: Available data suggest that SIRT in unresectable hepatocellular and cholangiocellular carcinomas can provide a considerable down-sizing of the tumors to possibly allow resection. Hypertrophy of the contra-lateral lobe represents a favorable collateral effect that can help in achieving safer subsequent major hepatectomy. In patients whose FLR volume represents the only surgical concern, portal vein embolization remains the treatment of choice.

Copyright @ 2016 S. Karger AG, Basel

\section{Introduction}

A liver resection with negative margins is the only potentially curative treatment in the majority of patients with primary malignant disease, either from hepatocellular carcinoma (HCC) or cholangiocellular carcinoma (CCC) $[1,2]$. Even in cases of tumor recurrence, surgery can still provide acceptable safety and comparable long-term survival rates to those after their first hepatectomy [3-5]. When evaluating patients for resection, two main aspects have to be considered to disqualify them from surgery resulting from an unresectable tumor. The first is represented by the close proximity of the tumor to normal vital hepatic structures such as the portal venous bifurcation, the bile duct bifurcation and/or the hepatic veins, which can make any type of intervention impossible. In these clinical circumstances, Selective internal radiation therapy (SIRT) radio-embolization (RE) with Yttrium-90 (Y90)labeled microspheres is currently adopted in a palliative setting for unresectable liver cancers $[6,7]$. SIRT has been shown to obtain partial and even complete response in unresectable primary and secondary tumors, demonstrating a good safety profile and achieving a survival benefit [6-8]. The second aspect is represented by the presence of an inadequate future liver remnant (FLR), which is imperative to avoid post-hepatectomy liver failure and premature death [9]. In this regard, portal vein embolization (PVE) is commonly performed to induce contra-lateral hypertrophy, allowing for safe major hepatectomy [9]. As a favorable collateral effect, SIRT has also been shown to induce liver hypertrophy of the untreated segments [6-8]. The aim of the present review is to explore the possibility of considering SIRT as conversion therapy for unresectable HCC/CCC, taking primarily into account the tumor response rates and, secondly, the increase in FLR volume achievable with RE in comparison to what can be obtained with PVE.

\section{Tumor Response after SIRT of Primary Liver Tumors}

The tumor involvement of normal vital hepatic structures is a common cause of unresectability. The possibility of obtaining an objective tumor response through SIRT, by shrinking the tumor and disengaging it from such structures can increase the chance of performing a hepatic resection [10]. Table 1 shows a summary of the response rates for CCC [11-19] derived from the current literature; one additional study was retrieved and reported separately [20]. Data regarding HCC were also summarized with some overlap of studies [21-31]. Taking the collated results together, a wide range of partial response (PR) rates can be estimated for CCC, from between $4.7 \%$ to $82.3 \%$, with most of the literature reporting a PR of around 25-35\% (RECIST [Response Evaluation Criteria in Solid Tumors] criteria), but with very low chances of obtaining a complete response (CR) [11-19]. However, some studies have reported necrosis of target lesions that can be more than $50 \%$ in up to $75 \%$ of CCCs 
Table 1. Summary of literature reporting response rates of HCC/CCC after SIRT

\begin{tabular}{|c|c|c|c|c|c|}
\hline Author (year) & $\begin{array}{l}\text { Patients } \\
\mathrm{n}^{\circ}\end{array}$ & $\begin{array}{l}\text { SIRT } \\
\text { modality }\end{array}$ & $\begin{array}{l}\text { Tumor response } \\
\text { criteria }\end{array}$ & $\begin{array}{l}\text { Tumor Response } \\
\text { rate }\end{array}$ & Median OS (mo) \\
\hline \multicolumn{6}{|l|}{ Cholangiocarcinoma } \\
\hline Soydal (2015) [11] & 16 & Resin & RECIST & PR: $30 \%$ & 9.8 \\
\hline Filippi (2015) [12] & 18 & Resin & RECIST & PR: $82.3 \%$ & 14.8 \\
\hline Camacho (2014) [13] & 21 & Resin & $\begin{array}{l}\text { RECIST } \\
\text { mRECIST } \\
\text { EASL }\end{array}$ & $\begin{array}{l}\text { PR: } 4.7 \% \\
\text { PR: } 62 \% \\
\text { PR: } 9.5 \%\end{array}$ & 16.3 \\
\hline Rafi (2013) [14] & 19 & Resin & RECIST & PR: $11 \%$ & 11.5 \\
\hline Mouli (2013) [15] & 46 & Glass & WHO & PR: $25 \%$ & $\begin{array}{l}14.6 \text { (solitary) } \\
5.7 \text { (multifocal) }\end{array}$ \\
\hline Hoffmann (2012) [16] & 33 & Resin & RECIST & PR: 36\% & 22 \\
\hline Haug (2011) [17] & 26 & Resin & RECIST & PR: $22 \%$ & 11.7 \\
\hline Saxena (2010) [18] & 25 & Resin & RECIST & PR: $26 \%$ & 9.3 \\
\hline Ibrahim (2008) [19] & 24 & Glass & WHO & PR: $27 \%$ & 14.9 \\
\hline \multicolumn{6}{|l|}{ HCC } \\
\hline $\begin{array}{l}\text { Mazzaferro (2013) } \\
{[21]}\end{array}$ & 52 & Glass & EASL & $\begin{array}{l}\text { CR: } 9.6 \% \\
\text { OR: } 40.4 \%\end{array}$ & 15 \\
\hline Salem (2011) [22] & 123 & Glass & $\begin{array}{l}\text { WHO/RECIST } \\
\text { EASL }\end{array}$ & $\begin{array}{l}\text { OR: } 49 \% \\
\text { OR: } 72 \%\end{array}$ & 20.5 \\
\hline Hilgard (2010) [22] & 108 & Glass & $\begin{array}{l}\text { WHO/RECIST } \\
\text { EASL }\end{array}$ & $\begin{array}{l}\text { OR: } 41 \% \\
\text { (CR 6\%; PR 35\%) } \\
\text { OR: 40\% } \\
\text { (CR 3\%; PR 37\%) }\end{array}$ & $\begin{array}{l}16.4 \\
10 \text { (PVTT) }\end{array}$ \\
\hline Salem (2010) [24] & 291 & Glass & EASL & $\begin{array}{l}\text { OR: } 57 \% \\
\text { (CR 23\%; PR 34\%) }\end{array}$ & $\begin{array}{l}17.2 \\
\text { (Child-Pugh A) } \\
7.7 \\
\text { (Child-Pugh B) }\end{array}$ \\
\hline Kooby (2010) [25] & 27 & Resin & WHO/RECIST & PR: $11 \%$ & 6 \\
\hline Carr (2010) [26] & 99 & Glass & WHO/RECIST & $\begin{array}{l}\text { OR: } 41 \% \\
\text { (CR 3\%; PR 38\%) }\end{array}$ & 11.5 \\
\hline $\begin{array}{l}\text { Lewandowski (2009) } \\
\text { [27] }\end{array}$ & 43 & Glass & $\begin{array}{l}\text { WHO/RECIST } \\
\text { EASL }\end{array}$ & $\begin{array}{l}\text { PR: } 61 \% \text { (CR 0\%) } \\
\text { OR: } 86 \% \\
\text { (CR 47\%; PR 39\%) }\end{array}$ & 35.7 \\
\hline Kulik (2008) [28] & 108 & Glass & $\begin{array}{l}\text { WHO/RECIST } \\
\text { EASL }\end{array}$ & $\begin{array}{l}\text { PR: } 42 \% \\
\text { RR: } 70 \%\end{array}$ & NR \\
\hline Sangro (2006) [29] & 24 & Resin & WHO/RECIST & $\begin{array}{l}\text { DC: } 100 \% \\
\text { RR: } 23.8 \%\end{array}$ & 7 \\
\hline Salem (2005) [30] & 43 & Glass & $\begin{array}{l}\text { WHO/RECIST } \\
\text { EASL }\end{array}$ & $\begin{array}{l}\text { PR: } 47 \% \\
\text { PR: } 79 \%\end{array}$ & $\begin{array}{l}24 \text { (Okuda I) } \\
13 \text { (Okuda II) }\end{array}$ \\
\hline Carr (2004) [31] & 65 & Glass & WHO/RECIST & PR: 38.4\% & $\begin{array}{l}21 \text { (Okuda I) } \\
10 \text { (Okuda II) }\end{array}$ \\
\hline
\end{tabular}

OS=overall survival; $O R \quad(P R+C R)=$ objective response; $\mathrm{DC}=$ disease control; $\mathrm{RR}=$ reduction rate; WHO=World Health Organization; mRECIST=modified RECIST; EASL=European Association for the Study of the Liver; PVTT=portal vein tumor thrombosis.

thereby leading to the down-sizing of the tumor $[15,19]$. For HCC, the CR rate is reported to be about $10 \%$ [21] with an objective response rate (RECIST) of about $40 \%$ [21-31]. It can be hypothesized, in the best clinical scenario, that a partial/objective response can be sufficient to induce the disengagement of the tumor from vital hepatic structures, which would 
otherwise represent the main surgical contraindication [20]. To the best of our knowledge, only one study from Rayar et al. [20] was specifically aimed at verifying the conversion rate from unresectability to resectability of CCC. In 37 patients with unresectable CCC, hepatectomy was finally performed in eight cases (21.6\%), all with tumor-negative margins [20]. Other surgical experiences after RE have been reported in the setting of neoadjuvant therapy rather than conversion therapy. In the study by Mouli et al.[15], five out of 46 patients with CCC were subsequently resected (10.8\%). Regarding HCC, still in the setting of neo-adjuvant therapy, in the 2010 study by Salem et al. [22], only two out of 291 patients with HCC were subsequently resected (1.6\%) and 32 were transplanted (11.0\%), respectively. Apart from down-staging possibilities allowing liver transplantation, the available literature suggests that RE can be followed by curative surgical treatment.

\section{Volumetric Changes after SIRT}

Along with studies demonstrating good tumor response rates after SIRT, several reports on volume changes in treated and untreated liver areas have been published in recent years. The most relevant aspect is that RE is able to induce contralateral hypertrophy. To date (as of November 2015), seven full articles and one abstract attempted to describe the time-dependent changes in liver volume [32-40]. A detailed list of collated studies is reported in Table 2. Taking available data together, even if obtained at different time-points after SIRT, it can be estimated that a maximum hypertrophy above $40 \%$ of the untreated segments can be expected. The optimal time to measurement of FLR is more complicated to ascertain. The studies by Fernandez-Ros et al. [35] and Vouche et al. [36] have suggested that the kinetics of post-Y90 hypertrophy are slow, with gradual increases in volume, and without a clear plateau. The latter study reported $45 \%$ hypertrophy at nine months, whereas the former study reported a similar figure at about six months, suggesting that other factors can influence the degree of growth that can be achieved. Of note, in the study by Vouche, of 83 patients deemed unresectable before SIRT , five subsequently underwent hepatic resection (6.0\%). Considering all the available information, it can be summarized that the literature reports an increase in the FLR at three months after RE ranging between 21 to 32\%; the longer the follow-up, the greater the amount of hypertrophy that can be obtained.

These studies reported on the phenomenon of post-SIRT hypertrophy as the primary outcome, but a consistent finding was that hypertrophy of the untreated lobe is accompanied by a corresponding decrease in size of the tumor-bearing hemi-liver, resulting in no net change in the liver volume. This suggests that SIRT results in both good local tumor control, consistent with previous studies reporting on oncological outcomes, and an increase of the FLR.

\section{SIRT Versus PVE}

Since its first description in 1986, PVE has been commonly adopted when faced with an inadequate FLR volume, with high technical and clinical success rates [41-43]. The morbidity is low but the local tumor progression after PVE can be a pending cause of unresectability, possibly due to the increased arterial supply to the tumor in the embolized hemiliver $[43,44]$. In the absence of close proximity or tumor engagement of normal vital hepatic structures, and when the only surgical concern is represented by an inadequate FLR volume, upfront hemihepatectomy after PVE is considered as the treatment of choice. This approach 
Table 2. Summary of literature reporting volumetric changes after SIRT

\begin{tabular}{|c|c|c|c|c|c|}
\hline Author (year) & $\begin{array}{l}\text { Patients } \\
\mathrm{n}^{\circ}\end{array}$ & Tumor types & $\begin{array}{l}\text { SIRT } \\
\text { modality }\end{array}$ & $\begin{array}{l}\text { Area of Y90 } \\
\text { treatment }\end{array}$ & $\begin{array}{l}\text { Hypertrophy of } \\
\text { untreated liver }\end{array}$ \\
\hline $\begin{array}{l}\text { Bishay (Abstract; } \\
\text { 2015) [32] }\end{array}$ & 15 & $\begin{array}{l}\text { HCC: } 33.3 \% \\
\text { CCC: } 26.7 \% \\
\text { Other: } 40 \%\end{array}$ & $\begin{array}{l}\text { Resin: } \\
100 \%\end{array}$ & Right lobe: $100 \%$ & $\begin{array}{l}\text { Maximal increase of } \\
30.7 \% \text { at } 6 \text { months; } \\
3 \text { months: } 29.1 \% \text {. }\end{array}$ \\
\hline $\begin{array}{l}\text { Theysohn (2014) } \\
\text { [33] }\end{array}$ & 45 & HCC: $100 \%$ & $\begin{array}{l}\text { Glass: } \\
100 \%\end{array}$ & Right lobe: $100 \%$ & $\begin{array}{l}\text { Maximal increase of } \\
50.5 \% \text { at } 6 \text { months; } \\
3 \text { months: } 45.4 \%\end{array}$ \\
\hline Teo (2014) [34] & 17 & HCC: $100 \%$ & $\begin{array}{l}\text { Resin: } \\
100 \%\end{array}$ & Right lobe: $100 \%$ & $\begin{array}{l}\text { Mean FLR increase of } \\
42.3 \% \text { at a median of } \\
5 \text { months of follow-up }\end{array}$ \\
\hline $\begin{array}{l}\text { Fernández-Ros } \\
\text { (2014) [35] }\end{array}$ & 83 & $\begin{array}{l}\text { HCC: } 62.7 \% \\
\text { CCC: } 4.8 \% \\
\text { Other: } 32.5 \%\end{array}$ & $\begin{array}{l}\text { Resin: } \\
100 \%\end{array}$ & $\begin{array}{l}\text { Right hemi-liver: } \\
72.3 \% \\
\text { Left hemi-liver: } \\
16.9 \%\end{array}$ & $\begin{array}{l}\text { Maximal increase of } \\
45.0 \% \text { at } 6.5 \text { months; } \\
3 \text { months: } 18.0 \%\end{array}$ \\
\hline $\begin{array}{l}\text { Vouche (2013) } \\
\text { [36] }\end{array}$ & 83 & $\begin{array}{l}\text { HCC: } 80.7 \% \\
\text { CCC: } 9.6 \% \\
\text { Other: } 9.7 \%\end{array}$ & $\begin{array}{l}\text { Glass: } \\
100 \%\end{array}$ & Right lobe: $100 \%$ & $\begin{array}{l}\text { Maximal increase of } 45 \% \\
\text { after } 9 \text { months from } \\
\text { SIRT; } 3 \text { months: } 24 \%\end{array}$ \\
\hline $\begin{array}{l}\text { Ahmadzadehfar } \\
\text { (2013) [37] }\end{array}$ & 24 & $\begin{array}{l}\text { mCRC: } 62.5 \% \\
\text { Other mets: } \\
37.5 \%\end{array}$ & $\begin{array}{l}\text { Resin: } \\
100 \%\end{array}$ & $\begin{array}{l}\text { Right lobe: } 100 \% \\
\text { ( } 7 \text { pts subsequent } \\
\text { left lobe) }\end{array}$ & $\begin{array}{l}\text { Maximal increase of } \\
47.0 \% \text { observed after a } \\
\text { median of } 44 \text { days from } \\
\text { SIRT. }\end{array}$ \\
\hline $\begin{array}{l}\text { Edeline (2013) } \\
{[38]}\end{array}$ & 34 & HCC: $100 \%$ & $\begin{array}{l}\text { Glass: } \\
88.2 \% \\
\text { Resin: } \\
11.8 \%\end{array}$ & $\begin{array}{l}\text { Right hemi-liver: } \\
67.6 \% \\
\text { Left hemi-liver: } \\
32.4 \%\end{array}$ & $\begin{array}{l}\text { Maximal increase of } 42 \% \\
\text { at a median of } 6.5 \text { from } \\
\text { RE; } 3 \text { months: } 29 \%\end{array}$ \\
\hline $\begin{array}{l}\text { Garlipp (2013) } \\
\text { [39] }\end{array}$ & 26 & $\begin{array}{l}\text { mCRC: } 46.2 \% \\
\text { Other mets: } \\
53.8 \%\end{array}$ & $\begin{array}{l}\text { Resin: } \\
100 \%\end{array}$ & Right lobe: $100 \%$ & $\begin{array}{l}\text { Observed increase at a } \\
\text { median of } 46 \text { days: } 29 \% \\
\text { (median) }\end{array}$ \\
\hline $\begin{array}{l}\text { Gaba (2009) } \\
{[40]}\end{array}$ & 20 & $\begin{array}{l}\text { HCC: } 85 \% \\
\text { CCC: } 15 \%\end{array}$ & $\begin{array}{l}\text { Glass: } \\
100 \%\end{array}$ & Right lobe: $100 \%$ & $\begin{array}{l}\text { At a mean of } 18 \text { months } \\
\text { follow-up the median } \\
\text { increase was of } 40 \%\end{array}$ \\
\hline
\end{tabular}

$\mathrm{mCRC}=$ colorectal-cancer liver metastases; mets=metastases.

does not only have greater clinical evidence of effectiveness [43], it can be considered as the most cost effective, given the high costs of SIRT [45]. However, in the presence of involvement of non-expendable anatomical hepatic structures during surgery, it seems reasonable to proceed with SIRT knowing that contra-lateral hypertrophy can be obtained. In this regard, only one study [39] has to date, attempted a direct head-to-head comparison between SIRT and PVE in terms of liver hypertrophy. Garlipp et al. [39] performed a matched-pair analysis of patients with secondary liver malignancy confined to the right hemi-liver. Patients were well matched for baseline FLR, a history of platinum-based chemotherapy, platelet count, and extent of embolization. Although subject to the usual biases inherent in such a study, PVE was reported to result in significantly greater hypertrophy (PVE: 61.5\% and SIRT: 29.0\%) within a shorter median time frame (PVE: 33 days, range 24-56 days; SIRT: 46 days, range 27-79 days). Tumor growth rates in both arms were not reported in this study. Other factors known to interfere with the regenerative capacity of the liver, such as liver cirrhosis and portal hypertension, were excluded from the analysis, making the results more reliable. Of note, in the analysis of the initial 35 patients included in this study, $50 \%$ of subjects who had a baseline FLR ratio less than $25 \%$ showed an increase above $25 \%$ at follow-up, suggesting that volume hypertrophy induced by SIRT may be sufficient to achieve an adequate FLR volume in a con- 
siderable proportion of patients. The authors suggested that RE with the aim of inducing hypertrophy may be preferable to PVE in patients whose lesions are at risk of becoming unresectable due to invasion of normal vital structures if tumor progression occurs. In patients who need only a maximum FLR volume increase, without immediate threatening of the potential plane of resection, PVE may remain the treatment of choice. At this point, the safety of the two procedures should be mentioned. Taking into consideration the largest SIRT experience published to date for primary tumors, a transient increase in bilirubin within the first month after RE has been observed in about half the cases, persisting at three months in only $5.8 \%$ of patients, but without irreversible liver failure directly ascribed to SIRT [8]. These figures are slightly higher than the all-causes major complication rates reported after PVE $(2.5 \%)[43,44]$.

\section{Area for Future Surgical Development}

As stated previously, patients receiving SIRT are not typically surgical candidates. As the final result of RE, the main benefit obtainable in patients with HCC/CCC, initially deemed unresectable, could be represented by the down-sizing of the tumor, disengagement of the tumor from normal vital hepatic structures, and allowing potential subsequent major hepatectomy. It should be noted that the response to SIRT can effectively cause the tumor to become detached from blood vessels, but that the fibrotic effect on the surrounding parenchyma can still represent a technical problem in disengaging the tumor from such structures. This aspect must be considered when evaluating resectability after RE. The simultaneous increase in the FLR volume should be considered as a favorable "side effect" of a treatment primarily designed to prevent tumor progression in the embolized lobe. All studies published to date, except one, have reported the number of patients successfully resected (or transplanted) after RE in the setting of a neo-adjuvant approach, which is an additional aspect to the effectiveness of SIRT. However, there is still a scarcity of literature from an intention-to-treat point of view aimed at verifying tumor conversion rates after SIRT. In this regard, unresectability must be clearly defined to delimit the field of SIRT as such a therapy. Unresectable cancers are those that cannot be removed due either to the number of metastatic foci, or because the tumor is in a surgical danger zone, with (or without) an insufficient FLR to avoid postoperative liver failure. The unresectability criteria used in the study by Garlipp et al. [39] can fulfil these semantic features: patients considered having unresectable local disease were candidates for extended hepatic resections with insufficient FLR and/or with close proximity of the tumor to normal vital structures (portal vein bifurcation/bile duct bifurcation/inferior vena cava or supra-hepatic veins) that can not be preserved or reconstructed during surgery. Such patients should be enrolled in a study of the effectiveness of SIRT as a conversion therapy. It must be emphasized that SIRT cannot replace PVE in patients whose FLV represents the only surgical concern considering the need to preserve a FLR of at least $30 \%$ in patients without chronic liver disease and of at least $40 \%$ in patients with chronic liver disease [9].

\section{Conclusions}

The available literature suggests that in a considerable proportion of patients with primary liver tumors, a good response can be expected after SIRT. Even if incomplete, a PR may also be sufficient to disengage the tumor from normal vital structures, allowing for sub- 
sequent surgical resection. Multidisciplinary committees must include expert hepatobiliary surgeons, not only to judge the unresectability of tumors, but also to judge the possibility of performing hepatectomy once down-sizing of the tumor (as well as hypertrophy of the contra-lateral lobe) is achieved. Intention-to-treat studies in this regard are warranted.

\section{Disclosure}

No sponsorship of funding arrangements to disclose for any of the Authors in relationship with the present manuscript.

\section{Conflict of Interest}

None declared.

\section{References}

1 Shi M, Guo RP, Lin XJ, Zhang YQ, Chen MS, Zhang CQ, Lau WY, Li JQ: Partial hepatectomy with wide versus narrow resection margin for solitary hepatocellular carcinoma: a prospective randomized trial. Ann Surg 2007;245:36-43.

2 Cucchetti A, Bertuzzo V, Pinna AD: Can Positive Resection Margin of Intra-hepatic Cholangiocarcinoma Still Provide a Survival Benefit over Systemic Chemotherapy? World J Surg 2015;39:2965-2966

3 Wu CC, Cheng SB, Yeh DC, Wang J, P'eng FK: Second and third hepatectomies for recurrent hepatocellular carcinoma are justified. Br J Surg 2009;96:1049-1057.

4 Zhou Y, Sui C, Li B, Yin Z, Tan Y, Yang J, Liu Z: Repeat hepatectomy for recurrent hepatocellular carcinoma: a local experience and a systematic review. World J Surg Oncol 2010;8:55.

5 Sulpice L, Rayar M, Boucher E, Pracht M, Meunier B, Boudjema K: Treatment of recurrent intrahepatic cholangiocarcinoma. Br J Surg 2012;99:1711-1717.

6 Edeline J, Gilabert M, Garin E, Boucher E, Raoul JL: Yttrium-90 microsphere radioembolization for hepatocellular carcinoma. Liver Cancer 2015;4:16-25.

7 Sangro B, Carpanese L, Cianni R, Golfieri R, Gasparini D, Ezziddin S, Paprottka PM, Fiore F, Van Buskirk M, Bilbao JI, Ettorre GM, Salvatori R, Giampalma E, Geatti O, Wilhelm K, Hoffmann RT, Izzo F, Iñarrairaegui M, Maini CL, Urigo C, Cappelli A, Vit A, Ahmadzadehfar H, Jakobs TF, Lastoria S, European Network on Radioembolization with Yttrium-90 Resin Microspheres (ENRY): Survival after yttrium-90 resin microsphere radioembolization of hepatocellular carcinoma across Barcelona clinic liver cancer stages: a European evaluation. Hepatology 2011;54:868-878.

8 Khajornjiraphan N, Thu NA, Chow PK: Yttrium-90 microspheres: a review of its emerging clinical indications. Liver Cancer 2015;4:6-15.

9 Eshkenazy R, Dreznik Y, Lahat E, Zakai BB, Zendel A, Ariche A: Small for size liver remnant following resection: prevention and management. Hepatobiliary Surg Nutr 2014;3:303-312.

10 Braat AJ, Huijbregts JE, Molenaar IQ, Borel Rinkes IH, van den Bosch MA, Lam MG: Hepatic radioembolization as a bridge to liver surgery. Front Oncol 2014;4:199.

11 Soydal C, Kucuk ON, Bilgic S, Ibis E: Radioembolization with 90Y resin microspheres for intrahepatic cholangiocellular carcinoma: prognostic factors. Ann Nucl Med 2016;30:29-34.

12 Filippi L, Pelle G, Cianni R, Scopinaro F, Bagni O: Change in total lesion glycolysis and clinical outcome after (90)Y radioembolization in intrahepatic cholangiocarcinoma. Nucl Med Biol 2015;42:59-64.

13 Camacho JC, Kokabi N, Xing M, Prajapati HJ, El-Rayes B, Kim HS: Modified response evaluation criteria in solid tumors and European Association for The Study of the Liver criteria using delayed-phase imaging at an early time point predict survival in patients with unresectable intrahepatic cholangiocarcinoma following yttrium-90 radioembolization. J Vasc Interv Radiol 2014;25:256-265.

14 Rafi S, Piduru SM, El-Rayes B, Kauh JS, Kooby DA, Sarmiento JM, Kim HS: Yttrium-90 radioembolization for unresectable standard-chemorefractory intrahepatic cholangiocarcinoma: survival, efficacy, and safety study. Cardiovasc Intervent Radiol 2013;36:440-448.

15 Mouli S, Memon K, Baker T, Benson AB 3rd, Mulcahy MF, Gupta R, Ryu RK, Salem R, Lewandowski RJ: Yttrium-90 radioembolization for intrahepatic cholangiocarcinoma: safety, response, and survival analysis. J Vasc Interv Radiol 2013;24:1227-1234. 
16 Hoffmann RT, Paprottka PM, Schön A, Bamberg F, Haug A, Dürr EM, Rauch B, Trumm CT, Jakobs TF, Helmberger TK, Reiser MF, Kolligs FT: Transarterial hepatic yttrium-90 radioembolization in patients with unresectable intrahepatic cholangiocarcinoma: factors associated with prolonged survival. Cardiovasc Intervent Radiol 2012;35:105-116.

17 Haug AR, Heinemann V, Bruns CJ, Hoffmann R, Jakobs T, Bartenstein P, Hacker M: 18F-FDG PET independently predicts survival in patients with cholangiocellular carcinoma treated with 90Y microspheres. Eur J Nucl Med Mol Imaging 2011;38:1037-1045.

18 Saxena A, Bester L, Chua TC, Chu FC, Morris DL: Yttrium-90 radiotherapy for unresectable intrahepatic cholangiocarcinoma: a preliminary assessment of this novel treatment option. Ann Surg Oncol 2010;17:484-491.

19 Ibrahim SM, Mulcahy MF, Lewandowski RJ, Sato KT, Ryu RK, Masterson EJ, Newman SB, Benson A 3rd, Omary RA, Salem R: Treatment of unresectable cholangiocarcinoma using yttrium-90 microspheres: results from a pilot study. Cancer 2008;113:2119-2128.

20 Rayar M, Sulpice L, Edeline J, Garin E, Levi Sandri GB, Meunier B, Boucher E, Boudjema K: Intra-arterial yttrium-90 radioembolization combined with systemic chemotherapy is a promising method for downstaging unresectable huge intrahepatic cholangiocarcinoma to surgical treatment. Ann Surg Oncol 2015;22:3102-3108.

21 Mazzaferro V, Sposito C, Bhoori S, Romito R, Chiesa C, Morosi C, Maccauro M, Marchianò A, Bongini M, Lanocita R, Civelli E, Bombardieri E, Camerini T, Spreafico C: Yttrium-90 radioembolization for intermediate-advanced hepatocellular carcinoma: a phase 2 study. Hepatology 2013;57:1826-1837.

22 Salem R, Lewandowski RJ, Kulik L, Wang E, Riaz A, Ryu RK, Sato KT, Gupta R, Nikolaidis P, Miller FH, Yaghmai V, Ibrahim SM, Senthilnathan S, Baker T, Gates VL, Atassi B, Newman S, Memon K, Chen R, Vogelzang RL, Nemcek AA, Resnick SA, Chrisman HB, Carr J, Omary RA, Abecassis M, Benson AB 3rd, Mulcahy MF: Radioembolization results in longer time-to-progression and reduced toxicity compared with chemoembolization in patients with hepatocellular carcinoma. Gastroenterology 2011;140:497-507, e2.

23 Hilgard P, Hamami M, Fouly AE, Scherag A, Müller S, Ertle J, Heusner T, Cicinnati VR, Paul A, Bockisch A, Gerken G, Antoch G: Radioembolization with yttrium-90 glass microspheres in hepatocellular carcinoma: European experience on safety and long-term survival. Hepatology 2010;52:1741-1749.

24 Salem R, Lewandowski RJ, Mulcahy MF, Riaz A, Ryu RK, Ibrahim S, Atassi B, Baker T, Gates V, Miller FH, Sato KT, Wang E, Gupta R, Benson AB, Newman SB, Omary RA, Abecassis M, Kulik L: Radioembolization for hepatocellular carcinoma using Yttrium-90 microspheres: a comprehensive report of long-term outcomes. Gastroenterology 2010;138:52-64.

25 Kooby DA, Egnatashvili V, Srinivasan S, Chamsuddin A, Delman KA, Kauh J, Staley CA 3rd, Kim HS: Comparison of yttrium-90 radioembolization and transcatheter arterial chemoembolization for the treatment of unresectable hepatocellular carcinoma. J Vasc Interv Radiol 2010;21:224-230.

26 Carr BI, Kondragunta V, Buch SC, Branch RA: Therapeutic equivalence in survival for hepatic arterial chemoembolization and yttrium 90 microsphere treatments in unresectable hepatocellular carcinoma: a two-cohort study. Cancer 2010;116:1305-1314.

27 Lewandowski RJ, Kulik LM, Riaz A, Senthilnathan S, Mulcahy MF, Ryu RK, Ibrahim SM, Sato KT, Baker T, Miller FH, Omary R, Abecassis M, Salem R: A comparative analysis of transarterial downstaging for hepatocellular carcinoma: chemoembolization versus radioembolization. Am J Transplant 2009;9:1920-1928.

28 Kulik LM, Carr BI, Mulcahy MF, Lewandowski RJ, Atassi B, Ryu RK, Sato KT, Benson A 3rd, Nemcek AA Jr, Gates VL, Abecassis M, Omary RA, Salem R: Safety and efficacy of 90Y radiotherapy for hepatocellular carcinoma with and without portal vein thrombosis. Hepatology 2008;47:71-81.

29 Sangro B, Bilbao JI, Boan J, Martinez-Cuesta A, Benito A, Rodriguez J, Panizo A, Gil B, Inarrairaegui M, Herrero I, Quiroga J, Prieto J: Radioembolization using 90Y-resin microspheres for patients with advanced hepatocellular carcinoma. Int J Radiat Oncol Biol Phys 2006;66:792-800.

30 Salem R, Lewandowski RJ, Atassi B, Gordon SC, Gates VL, Barakat O, Sergie Z, Wong CY, Thurston KG: Treatment of unresectable hepatocellular carcinoma with use of 90Y microspheres (TheraSphere): safety, tumor response, and survival. J Vasc Interv Radiol 2005;16:1627-1639.

31 Carr BI: Hepatic arterial 90Yttrium glass microspheres (Therasphere) for unresectable hepatocellular carcinoma: interim safety and survival data on 65 patients. Liver Transpl 2004;10(Suppl 1):S107-S110.

32 Bishay V, Edwards M, Lo G, Patel RS, Fischman AM, Kim E, Nowakowski F, Lookstein RA: Hypertrophy of future liver remnant in unresectable liver cancer following radioembolization with resin microspheres. J Vasc Interv Radiol 2015;2:S91.

33 Theysohn JM, Ertle J, Müller S, Schlaak JF, Nensa F, Sipilae S, Bockisch A, Lauenstein TC: Hepatic volume changes after lobar selective internal radiation therapy (SIRT) of hepatocellular carcinoma. Clin Radiol 2014;69:172-178.

34 Teo JY, Goh BK, Cheah FK, Allen JC, Lo RH, Ng DC, Goh AS, Khor AY, Sim HS, Ng JJ, Chow PK: Underlying liver disease influences volumetric changes in the spared hemiliver after selective internal radiation therapy with 90Y in patients with hepatocellular carcinoma. J Dig Dis 2014;15:444-450.

35 Fernández-Ros N, Silva N, Bilbao JI, Iñarrairaegui M, Benito A, D’Avola D, Rodriguez M, Rotellar F, Pardo F, Sangro B: Partial liver volume radioembolization induces hypertrophy in the spared hemiliver and no major signs of portal hypertension. HPB Oxf 2014;16:243-249.

36 Vouche M, Lewandowski RJ, Atassi R, Memon K, Gates VL, Ryu RK, Gaba RC, Mulcahy MF, Baker T, Sato K, Hickey R, Ganger D, Riaz A, Fryer J, Caicedo JC, Abecassis M, Kulik L, Salem R: Radiation lobectomy: timedependent analysis of future liver remnant volume in unresectable liver cancer as a bridge to resection. J Hepatol 2013;59:1029-1036. 
37 Ahmadzadehfar H, Meyer C, Ezziddin S, Sabet A, Hoff-Meyer A, Muckle M, Logvinski T, Schild HH, Biersack HJ, Wilhelm K: Hepatic volume changes induced by radioembolization with 90 Y resin microspheres. A single-centre study. Eur J Nucl Med Mol Imaging 2013;40:80-90.

38 Edeline J, Lenoir L, Boudjema K, Rolland Y, Boulic A, Le Du F, Pracht M, Raoul JL, Clément B, Garin E, Boucher E: Volumetric changes after (90)y radioembolization for hepatocellular carcinoma in cirrhosis: an option to portal vein embolization in a preoperative setting? Ann Surg Oncol 2013;20:2518-2525.

39 Garlipp B, de Baere T, Damm R, Irmscher R, van Buskirk M, Stübs P, Deschamps F, Meyer F, Seidensticker R, Mohnike K, Pech M, Amthauer H, Lippert H, Ricke J, Seidensticker M: Left-liver hypertrophy after therapeutic right-liver radioembolization is substantial but less than after portal vein embolization. Hepatology 2014;59:1864-1873.

40 Gaba RC, Lewandowski RJ, Kulik LM, Riaz A, Ibrahim SM, Mulcahy MF, Ryu RK, Sato KT, Gates V, Abecassis MM, Omary RA, Baker TB, Salem R: Radiation lobectomy: preliminary findings of hepatic volumetric response to lobar yttrium-90 radioembolization. Ann Surg Oncol 2009;16:1587-1596.

41 Kinoshita H, Sakai K, Hirohashi K, Igawa S, Yamasaki O, Kubo S: Preoperative portal vein embolization for hepatocellular carcinoma. World J Surg 1986;10:803-808.

42 Sugawara Y, Yamamoto J, Higashi H, Yamasaki S, Shimada K, Kosuge T, Takayama T, Makuuchi M: Preoperative portal embolization in patients with hepatocellular carcinoma. World J Surg 2002;26:105-110.

43 van Lienden KP, van den Esschert JW, de Graaf W, Bipat S, Lameris JS, van Gulik TM, van Delden OM: Portal vein embolization before liver resection: a systematic review. Cardiovasc Intervent Radiol 2013;36:25-34.

44 Loffroy R, Favelier S, Chevallier O, Estivalet L, Genson PY, Pottecher P, Gehin S, Krausé D, Cercueil JP: Preoperative portal vein embolization in liver cancer: indications, techniques and outcomes. Quant Imaging Med Surg 2015;5:730-739.

45 Loveman E, Jones J, Clegg AJ, Picot J, Colquitt JL, Mendes D, Breen DJ, Moore E, George S, Poston G, Cunningham D, Ruers T, Primrose J: The clinical effectiveness and cost-effectiveness of ablative therapies in the management of liver metastases: systematic review and economic evaluation. Health Technol Assess 2014;18:vii-viii, 1-283. 